\title{
Impact of Different Geographical Locations on Genetic Variation and Phytochemical Constituents of Two Medicinal Marine Algae
}

\author{
*Amal Ibrahim Saleh and Hala El-Atroush \\ Botany Department, Faculty of Science, Ain Shams University, Cairo, 11566, Egypt. \\ *Corresponding author: amalsaleh@sci.asu.edu.eg, amalsaleh77@hotmail.com
}

\begin{abstract}
Genetic variations and phytochemical constituents of Dictyota dichotoma and Sargassum dentifolium, collected from Hurghada and Abu-Qir bay, were investigated. Results revealed an increase in the concentrations of carotenoids, sugars and DPPH\% in the samples of both algal species collected from Hurghada as compared with those collected from Abu-Qir. Regarding the samples collected from Hurghada, an increase in the concentrations of chlorophyll a, $b$ and phenols was recorded in $S$. dentifolium; while a decrease in chlorophyll a, b only was observed in $D$. dichotoma. No significant difference was observed in phenol concentrations between $D$. dichotoma samples collected from the two studied localities. DNA was isolated and thirteen SCoT molecular markers were used to detect the genetic variations between the samples of the two localities. In $D$. dichotoma, the total average of polymorphism is $56.68 \%$. SCoT-1 exhibited the highest polymorphism (80\%), while SCoT-28 recorded the lowest polymorphism (35.71\%). In S. dentifolium, the total average of polymorphism is $61.63 \%$. SCoT-3 showed the highest polymorphism ( $90 \%)$, while SCoT-13 exhibited the lowest polymorphism $(0.09 \%)$. In addition, BSI factor showed a marked difference between the two studied algae that it was $0.87 \%$ in $D$. dichotoma and $0.77 \%$ in $S$. dentifolium. Variation in geographical location affects genetic variation and phytochemical composition of $D$. dichotoma and $S$. dentifolium. The difference in the responses of the two studied algae to the change of locality and environmental conditions may reflect differences in their gene expression. Moreover, the efficiency of SCoT markers to discriminate between algal species collected from different localities has been confirmed.
\end{abstract}

Keywords: Dictyota dichotoma, genetic variation, molecular markers, phytochemical composition, Sargassum dentifolium, SCoT

\section{Introduction}

Marine macroalgae (seaweeds) are a diverse group of organisms that play a vital role in the productivity, structure, and function of coastal ecosystems (Dawes and Mathiesen, 2008). They are considered as a good source of vitamins, fibers, proteins, polyunsaturated fatty acids and other important secondary metabolites that are used in traditional medicine applications (Cho et al., 2011 and Ali et al., 2017).These metabolites are of potential pharmaceutical value with antibacterial, antiviral, antifungal, anticancer, anticonvulsant and antioxidant activities (Yuan et al., 2005; Zubia et al., 2007; Baleta et al., 2017; Rajkumar et al. 2018; Yende et al., 2018; Maddah et al., 2019; Madkour et al., 2019; Mohamed and Saber, 2019 and Sujatha et al., 2019). They are used as bio-fertilizers (Hashem et al., 2019), as biofuel, human food, animal fodder and used for hydrocolloid production (Bruton et al., 2009). They are known as an effective bioindicators to monitor the toxicity caused by heavy metals (Geelani et al., 2012).

Marine environment becomes the most explored habitat due to its biological and chemical diversity (Kim, 2012). Brown macroalgae considered as one of the most common and diversified seaweeds in Egyptian coasts. The brown alga Dictyota dichotoma (Hudson) J.V. Lamouroux is a member of class Phaeophyceae, order Dictyotales and family Dictyotaceae and it markedly flourishes in autumn and approaching climax during the cold period (Deyab et al., 2017). Rabanala et al. (2014) reported that $D$. dichotoma is the only cosmopolitan species of the genus Dictyota and so it has a widespread occurrence. Several studies have been carried out to study the chemical constituents and the 
medicinal potential of $D$. dichotoma. It considered as one of the most promising seaweeds due to its considerable nutritive and therapeutic value (Fathy, 2007; Demirel et al., 2009; Khallil et al., 2015; Deyab et al., 2016 \& 2017 and Ward et al., 2017). Sargassum is one of the marine macroalgae that widely distributed in tropical and temperate regions (Baleta et al., 2017). It belongs to class Phaeophyceae, order Fucales and family Sargassaceae. Different extracts of Sargassum dentifolium (Turner) C. Agardh have been proved to have insecticidal, antibacterial, antigenotoxic and antiviral effects, as well as a protective effect against induced hepatitis in rats (Salem et al., 2011; Madkour et al., 2012; Matloub et al., 2012 and Gamal-Eldeen et al., 2013).

Morphological characters have been traditionally used to differentiate between seaweed taxa (Mathieson et al. 1981). Nevertheless, the morphology alone cannot distinguish strains that have various shapes in diverse environmental conditions due to the morphological plasticity of algae (Wolf et al., 2012). Molecular and genetic characters are more stable than morphological characters because they are less affected by environmental conditions (Chikkaswamy and Paramanik, 2016). The combination of molecular and morphological analyses provides a strong and more accurate way to differentiate between organisms. In addition, biochemical analyses have been proved to be effective in discrimination of different algal species (Ismail and Mohamed, 2017).

Molecular markers are the most efficient tools which provide new ways for detecting DNA damage (Savva, 1994) as compared with other methods such as morphological, physiological and biochemical investigations (Chen et al., 2010 and Luo et al., 2014).Genetic analyses, based on molecular markers hold the promise of increased interpretation of macrophyte identities when linked with other studies (Elsaied et al., 2015). Mannschreck et al. (2002) used AFLP (Amplified Fragment Length Polymorphism) to detect the genetic diversity in Chara species.

Start Codon Targeted marker (SCoT) was first established by Collard and Mackill (2009). It is constructed using single primer in a PCR amplification reaction and based on the conserved regions which are surrounded by the start codon ATG (Sawant et al., 1999). SCoT marker has been used in many plant species such as rice (Collard and Mackill, 2009), potato (Gorji et al., 2011), sugarcane (Que et al., 2014) and rose (Agarwal et al., 2019), but according to available literature, there are no studies concerned with the use of SCoT marker in marine macroalgae or algae as a general.

Up to now, information about the influence of different localities on the phytochemical composition and the genetic variation of Egyptian seaweeds is scarce. Abd El Fatah et al. (2015) used SSR-PCR and ISSR-PCR based techniques as well as morphological examination to differentiate between four Chara samples collected from different habitats in Egypt. Mansour et al. (2018) studied the influence of different habitats on the chemical constituents and protein profiles of Codium tomentosum, collected from Red and Mediterranean Seas. The increasing demand for macroalgal natural products attracts the attention of many researchers to investigate algae. Studying the effect of environmental factors and geographical location on the genetic variation and phytochemical components of algae may through more light on the favorable conditions for the production of important algal secondary metabolites and from where we can collect the algae to obtain maximum yield of the target components. The present work aimed to study the impact of two different geographical locations on the genetic variation and phytochemical constituents of two medicinal macroalgal species, namely Dictyota dichotoma and Sargassum dentifolium. It also aimed to evaluate the efficiency of SCoT markers to discriminate between the two algal species.

\section{Material and methods}

\section{Collection of algal samples:}

Samples of Dictyota dichotoma and Sargassum dentifolium were collected during autumn 2018 from Red Sea (Hurghada) and Mediterranean Sea (Abu-Qir Bay), Egypt. The collected samples were washed with sea water and then kept in ice box and directly 
transported to the laboratory. Macroalgae were carefully washed with tap water and then with distilled water and dried with tissue paper. Algal samples were identified according to Aleem (1993). Samples were divided into two parts: the first for phytochemical analysis and the second for molecular analysis.

\section{I-Physico-chemical analysis:}

Water temperature and $\mathrm{pH}$ were measured directly in the field using portable $\mathrm{pH}$ meter with thermometer (AZ Model:8686). Dissolved oxygen concentration in water was determined in situ using dissolved oxygen meter (JENWAY model 970). Salinity was measured according to APHA (2005).

\section{II-Phytochemical analysis:}

i- Estimation of Photosynthetic pigments:

Extraction of photosynthetic pigments (chlorophyll a, b and carotenoids) was carried out using $80 \%$ acetone and then estimated spectrophotometrically as recommended by Metzner et al. (1965).

ii- Estimation of total phenolic content: The total phenolic content of methanol algal extracts was determined using the FolinCiocalteu reagent according to the procedure of Žilić et al. (2012). The absorbance was measured at $725 \mathrm{~nm}$ against the solvent blank. The total phenolic content was determined by means of a calibration curve prepared with gallic acid, and expressed as mg of gallic acid equivalent (mg GAE) per gm of sample.

iii- Estimation of radical DPPH scavenging activity:

Free radical scavenging capacity of methanol algal extracts was determined using the stable DPPH (2, 2-diphenyl-1- picrylhydrazyl) according to Hwang and Do Thi (2014).The absorbance was read at $517 \mathrm{~nm}$ and percentage of $\mathrm{DPPH}$ radical scavenging activity was calculated using the following equation: DPPH scavenging activity $(\%)=[($ Ac-As $) / A c] \times 100$. Where, Ac is the absorbance of the control $(100 \mu \mathrm{L}$ of methanol solvent with $100 \mu \mathrm{L}$ of the DPPH solution), and (As) is the absorbance of the sample.

iv- Estimation of carbohydrates:

Soluble and insoluble sugars were extracted according to the method adopted by Homme et al. (1992) and Naguib (1963), respectively. Then they were estimated using anthrone reagent as described by Blakeney and Mutton (1980).

\section{III-Molecular analysis:}

i- Extraction and purification of genomic DNA:

DNA was extracted from the algal samples, Dictyota dichotoma and Sargassum dentifolium collected from Hurghada and AbuQir, by DNeasy Plant Mini Kit (Qiagen Santa Clarita, CA).

ii- Estimation of DNA concentration:

DNA concentration was determined by diluting the DNA 1:5 in $\mathrm{dH}_{2} \mathrm{O}$. The DNA samples were electrophoresed in $1 \%$ agarose gel against 10 $\mathrm{ug}$ of a DNA marker. Estimation of the DNA concentration in a given sample was achieved by comparing the degree of fluorescence of the unknown DNA band with the different bands in the DNA marker.

iii- SCoT reactions:

Thirteen SCoT primers were used in the detection of polymorphism among samples of Dictyota dichotoma and Sargassum dentifolium collected from Hurghada and AbuQir. These primers were synthesized by Metabion Corp., Germany. The primers code and nucleotide sequences are presented in Table (1). The PCR amplification reactions were carried out as modified by Ibrahim et al., (2016). Reactions were performed in $25 \mu \mathrm{l}$ volume composed of $1 \mathrm{x}$ reaction buffer, 0.2 $\mathrm{mM}$ of dNTPs, $1.5 \mathrm{mM} \mathrm{MgCl} 2,0.2 \mu \mathrm{M}$ of primer, 0.5 unit of Taq polymerase (Qiagen Ltd., Germany) and 50 ng of template DNA, in sterile distilled water.

iv -SCoT-thermocycling profile and detection of the PCR products:

PCR amplification of the DNA was performed in a Perkin Elmer thermal cycler 9700. The temperature profile in the different cycles was $94^{\circ} \mathrm{C}$ for $5 \mathrm{~min}$ followed by 40 cycles comprised of a denaturation step at $94^{\circ} \mathrm{C}$ for 1 min, an annealing step at $50^{\circ} \mathrm{C}$ for $1 \mathrm{~min}$ and an extension step at $72^{\circ} \mathrm{C}$ for $1.5 \mathrm{~min}$. The final cycle was a polymerization cycle for $7 \mathrm{~min}$ at $72^{\circ} \mathrm{C}$.PCR products were mixed with $5 \mu \mathrm{l}$ gel loading dye and resolved by electrophoresis in 
Table (1). List of SCoT primers used in DNA analysis

\begin{tabular}{lll}
\hline No & Primer code & Nucleotide sequence \\
\hline $\mathbf{1}$ & SCoT $\mathbf{- 1}$ & 5'-CAACAATGGCTACCACCA-3' \\
$\mathbf{2}$ & SCoT $\mathbf{- 2}$ & 5'-CAACAATGGCTACCACCC-3' \\
$\mathbf{3}$ & SCoT $\mathbf{- 3}$ & 5'-CAACAATGGCTACCACCG-3' \\
$\mathbf{4}$ & SCoT $\mathbf{- 4}$ & 5'-CAACAATGGCTACCACCT-3' \\
$\mathbf{5}$ & SCoT $\mathbf{- 5}$ & 5'-CAACAATGGCTACCACGA-3' \\
$\mathbf{6}$ & SCoT $\mathbf{- 1 1}$ & 5'-AAGCAATGGCTACCACCA-3' \\
$\mathbf{7}$ & SCoT $\mathbf{- 1 2}$ & 5'-ACGACATGGCGACCAACG-3' \\
$\mathbf{8}$ & SCoT $\mathbf{- 1 3}$ & 5'-ACGACATGGCGACCATCG-3' \\
$\mathbf{9}$ & SCoT $\mathbf{- 1 4}$ & 5'-ACGACATGGCGACCACGC-3' \\
$\mathbf{1 0}$ & SCoT $\mathbf{- 2 0}$ & 5'-ACCATGGCTACCACCGCG-3' \\
$\mathbf{1 1}$ & SCoT $\mathbf{- 2 2}$ & 5'-AACCATGGCTACCACCAC-3' \\
$\mathbf{1 2}$ & SCoT $\mathbf{- 2 8}$ & 5'-CCATGGCTACCACCGCCA-3' \\
$\mathbf{1 3}$ & SCoT $\mathbf{- 3 3}$ & 5'-CCATGGCTACCACCGCAG-3' \\
\hline
\end{tabular}

a $1.5 \%$ agarose gel containing ethidium as follows: an initial strand separation cycle at bromide $(0.5 \mathrm{mg} / \mathrm{ml})$ in $1 \mathrm{x}$ TBE buffer at 120 volts. A $100 \mathrm{bp}$ DNA ladder was used as molecular size standard. PCR products were visualized under UV light and documented using a TMXR+ Gel Documentation System (Bio-Rad). The band sharing index (BSI) was also calculated as a measure of similarity between two species using the following equation: $B S I=2 S /(C+D)$; where $S$ is the number of bands shared between two samples, $\mathrm{C}$ is the number of bands in the first samples and $\mathrm{D}$ the number of bands in the second samples. A BSI value of one indicates that two species are identical, while BSI value of zero denotes that two species are totally different (Savva, 2000).

\section{IV-Data analysis:}

Only the clearest and strongest SCoT bands from the resulted patterns were scored manually as present (1) or absent (0) to be used for further analysis. The binary results were converted into similarity matrix according to
Dice's coefficient (Sneath and Sokal, 1973). Dendograms based on the unweighed pair group method with arithmetic averages (UPGMA) (Sokal and Michener, 1958) were constructed using SPSS version 23 software.

Phytochemical data were expressed as mean value of the three replicates \pm standard deviation (SD). Data analysis was performed using Statistical Package for Social Science (SPSS) version 23 software. Data were compared using one-way ANOVA (analysis of variance). $\mathrm{P}$ value was considered significant at $\mathrm{P}<0.05$.

\section{Results and Discussion}

Results of physico-chemical analysis (Table 2) showed that the analyzed parameters (water temperature, $\mathrm{pH}$, salinity and dissolved oxygen) were relatively higher in Hurghada (at the coast of Red Sea) as compared with the values recorded in Abu-Qir (at the coast of Mediterranean Sea).

Results obtained in this study also showed variations in the pigment composition and some phytochemical constituents of Dictyota

Table (2). Some physico-chemical parameters of water collected from Abu-Qir bay and Hurghada shore

\begin{tabular}{lcc}
\hline \multicolumn{1}{c}{ Parameters } & Abu-Qir & Hurghada \\
\hline Water temperature $\left({ }^{\circ} \mathrm{c}\right)$ & 19 & 26 \\
$\mathrm{pH}$ & 8.4 & 8.6 \\
Salinity $(\%)$ & 38.2 & 40.4 \\
Dissolved oxygen $(\mathrm{mg} / \mathrm{l})$ & 5.3 & 5.6 \\
\hline
\end{tabular}


dichotoma and Sargassum dentifolium collected from Abu-Qir and Hurghada (Table 3). Chlorophylls and carotenoids are essential pigments of photosynthesis in algae. There is a significant decrease in mean concentrations of both chlorophyll a and chlorophyll b in the samples of $D$. dichotoma collected from Hurghada (4.56 and $3.73 \mu \mathrm{g} / \mathrm{g} \quad \mathrm{FW}$, respectively) as compared with those collected from Abu-Qir (5.72 and $4.1 \mu \mathrm{g} / \mathrm{g} \mathrm{FW}$, respectively). This decrease in chlorophyll content may be due to the increased salinity in Hurghada as compared with Abu-Qir. Salinity and temperature of the sea are the main physico-chemical factors which determine the local and regional distribution of seaweeds in euphotic coastal waters (Sjøtun et al., 2015). The present results are in agreement with the findings of Hiremath and Mathad (2010) and Kirrolia et al. (2011) who found that chlorophyll content of many algal species decreases as the salt concentration increased. They attributed the reduction in chlorophyll content at higher salinities to the toxic ionic and salt osmotic stress.

In case of $S$. dentifolium, it was found that concentrations of chlorophyll a and chlorophyll b were higher in the samples collected from Hurghada (9.19and $6.62 \mu \mathrm{g} / \mathrm{g}$ $\mathrm{FW}$, respectively) than those recorded in the samples collected from Abu-Qir (6.55 and $5.26 \mu \mathrm{g} / \mathrm{g} \mathrm{FW}$, respectively). In agreement with this result, Karsten and Kirst (1989) pointed out that chlorophyll a content of Bostrychia radicans increased with the increment of salinity level. In contrast, Sigaud and Aidar (1993) showed that temperature and salinity did not have an influence on the chlorophyll-a content per cell for Phaeodactylum triconutum and Tetraselmis gracilis. These contradictions about the relation between chlorophyll a content and salinity level may be due to the difference of the studied algal taxa. Gosch et al. (2012) reported that biochemical constituents of algae vary considerably according to species, habitat, growth stage, geographical location, and environmental conditions.

An increment of carotenoid concentrations in both Dictyota dichotoma and Sargassum dentifolium samples collected from Hurghada (7.31 and $9.33 \mu \mathrm{g} / \mathrm{g}$ FW, respectively) was observed as compared with those collected from Abu-Qir (6.16 and 7.25 $\mu \mathrm{g} / \mathrm{g}$ FW, respectively). In agreement with our results, Rao et al. (2007) found that increasing salinity

Table (3). Variations in the pigment composition and some phytochemical constituents of Dictyota dichotoma and Sargassum dentifolium collected from Abu-Qir bay and Hurghada shore

\begin{tabular}{|c|c|c|c|c|}
\hline \multirow[t]{2}{*}{ Parameters } & \multicolumn{2}{|c|}{ Dictyota dichotoma } & \multicolumn{2}{|c|}{ Sargassum dentifolium } \\
\hline & Abu-Qir & Hurghada & Abu-Qir & Hurghada \\
\hline Chl.a( $\mu \mathrm{g} / \mathrm{g}$ fwt $)$ & $5.72 \pm 0.1$ & $4.56 \pm 0.12$ & $6.55 \pm 0.3$ & $9.19 \pm 0.26$ \\
\hline Chl.b( $\mu \mathrm{g} / \mathrm{g}$ fwt $)$ & $4.1 \pm 0.72$ & $3.73 \pm 0.09$ & $5.26 \pm 0.32$ & $6.62 \pm 0.38$ \\
\hline $\begin{array}{l}\text { Carotenoids } \\
(\mu \mathrm{g} / \mathrm{g} \text { fwt })\end{array}$ & $6.16 \pm 0.22$ & $7.31 \pm 0.20$ & $7.25 \pm 0.45$ & $9.33 \pm 0.37$ \\
\hline $\begin{array}{l}\text { Total phenols } \\
\text { (mg GAE/gdwt) }\end{array}$ & $6.21 \pm 0.36^{*}$ & $6.37 \pm 0.05^{*}$ & $9.15 \pm 0.25$ & $12.35 \pm 0.52$ \\
\hline DPPH \% & $51.43 \pm 1.11$ & $56.63 \pm 1.5$ & $59.69 \pm 1.1$ & $64.47 \pm 0.25$ \\
\hline $\begin{array}{l}\text { Soluble sugars } \\
\text { (mg/g dwt) }\end{array}$ & $0.84 \pm 0.25$ & $1.3 \pm 0.04$ & $1.13 \pm 0.15$ & $1.56 \pm 0.04$ \\
\hline $\begin{array}{l}\text { Insoluble sugars } \\
\text { (mg/g dwt) }\end{array}$ & $90.62 \pm 0.1$ & $121.5 \pm 3.12$ & $100.26 \pm 1.9$ & $133.2 \pm 1.33$ \\
\hline $\begin{array}{l}\text { Total sugars } \\
\text { (mg/g dwt) }\end{array}$ & $91.46 \pm 0.1$ & $122.8 \pm 3.08$ & $101.39 \pm 1.72$ & $134.76 \pm 1.35$ \\
\hline
\end{tabular}


in the cultures of Botryococcus braunii results in a two-fold increase in the carotenoid concentration.

Phenolics are commonly known to be involved in chemical protective mechanisms of algae against abiotic stressors such as salinity and UV radiation and this is mainly due to their potent antioxidant properties (de la Coba et al., 2009).The two studied seaweeds behave differently as relevant to the changes in the total phenol concentrations recorded in the two different studied localities. In Sargassum dentifolium the total phenol concentration in the samples collected from Hurghada (12.35 mg GAE/g dwt) was significantly higher than those recorded in samples from Abu-Qir (9.15 mg GAE/g dwt); whereas in Dictyota dichotoma, no significant difference was recorded between the two investigated sites (6.37 and $6.21 \mathrm{mg} \mathrm{GAE} / \mathrm{g} \mathrm{dwt).} \mathrm{Jormalainen}$ and Honkanen (2008) demonstrated that concentrations of algal phenolic compounds vary according to habitat, season and local environmental factors such as salinity, light, and nutrient availability. Mansour et al. (2018) found that change in salinity level between Red Sea and Mediterranean Sea doesn't induce a significant difference in the total phenol content of Codium tomentosum. However, Connan and Stengel (2011) reported a negative relationship between phenolic levels and salinity increase in some species of brown algae. These contradictions between results may be due to different responses of different algal species to stress.

Antioxidants are specific compounds that save human, animal and plant cells from the damaging effects of free radicals (Ghasemzadeh and Ghasemzadeh, 2011). Natural antioxidants extracted from algae provide a valuable alternative to non - natural antioxidants and are vital bioactive compounds that play an important role against various diseases and protect the cells from oxidative damage (Munir et al., 2013). The free radical scavenging activity (DPPH\%) of the methanol extracts of both Dictyota dichotoma and Sargassum dentifolium behaves similarly as the higher activity in both macroalgae were recorded in Hurghada (56.63\%, 64.47\%, respectively), while the lower activities were recorded in the samples collected from AbuQir (51.43\%, 59.69\%, respectively). Mansour et al. (2018) referred the increased antioxidant capacity in the samples of Codium tomentosum collected from Red Sea to the relative increase in its salinity and temperature, as compared with values recorded in Mediterranean Sea, which considered as stimulator to the alga to produce different secondary metabolites to overcome the effect of these stressors.

In the present study, a direct relationship between total phenolic content and free radical scavenging activity (DPPH\%) has been observed in the case of Sargassum dentifolium; whereas no relation between them could be detected in Dictyota dichotoma. A positive relation between antioxidant capacity and the total phenolic content has been also indicated by Chai et al., 2015 and Pinteus et al., 2017.Inversely, Mamelona et al. (2007) and Cho et al. (2011) pointed out that the antioxidant capacity is not directly correlated with the total phenolic contents.

In Sargassum dentifolium, a significant increase in the mean concentrations of soluble, insoluble and total sugars (1.56, 133.2 and $134.76 \mathrm{mg} / \mathrm{g}$ dwt, respectively) were recorded in the samples collected from Hurghada in comparison with those collected from Abu-Qir (1.13, 100.26 and $101.39 \mathrm{mg} / \mathrm{g} \mathrm{dwt}$, respectively). This increase may be attributed to the increase in chlorophyll content in $S$. dentifolium with increasing salinity (40.4 \%o) which consequently resulted in higher photosynthesis rate, leading to increase sugar biosynthesis. The same pattern of the increase was also observed in Dictyota dichotoma that the mean concentrations of these sugars recorded in Hurghada (1.3, 121.5 and 122.8 $\mathrm{mg} / \mathrm{g}$ dwt, respectively) were markedly higher than those recorded in Abu-Qir (0.84, 90.62 and $91.46 \mathrm{mg} / \mathrm{g} \mathrm{dwt}$, respectively). Several studies reported that carbohydrates synthesis was stimulated under stress conditions (Kirrolia et al., 2011). Soluble sugars are known to play an important role in the osmotic regulation of cells during reproduction and stress (Gill et al., 2002). In agreement with the present results, Farghl et al. (2015) found that concentrations of both soluble and total carbohydrates in Chlorella salina have been 
increased with the increase in salinity level and they suggested that the defense strategy of this alga against salinity seemed to take place through increased soluble carbohydrate concentration rather than soluble protein. In contrast, the same authors reported a decrease in both soluble and total carbohydrates concentrations in Chlorella vulgaris concomitant with the increase in salinity level and they referred the difference between the two studied species to the difference in their defense mechanisms against salinity stress.

Marine algae live in composite habitats and exposed to extreme conditions. In order to cope with these environmental conditions, they yield a wide variety of unique biologically active metabolites; which act as a chemical defense system and support the algal survival in these difficult environments (FreilePelegrin and Robledo, 2014). Abu-Qir Bay has been indicated by many authors as a heavily polluted water body (Hemaida 2007; ElGohary et al. 2011; Abdel Ghani et al.2013 and Emam et al. 2013). It was observed that concentrations of pigments and different phytochemical constituents recorded in $D$. dichotoma collected from Abu-Qir were lower than those recorded in $S$. dentifolium collected from the same locality and the same observation was recorded in the samples collected from Hurghada (Table 3). This may indicate that $S$. dentifolium is more tolerant to different stresses than $D$. dichotoma. The difference in the response of the two studied algae to the change of locality as well as environmental conditions might reflect differences in their gene expression.

\section{Genetic variation in Dictyota dichotoma}

The results obtained in this study showed that thirteen SCoT primers amplified a total number of 187 bands, of which 106 were polymorphic fragments and 81 monomorphic bands. The SCoT fingerprinting pattern detected by thirteen primers is shown in Fig. (1) and Table (4). The mean number of polymorphic bands per primer was 3.2 and the total average of polymorphism $56.68 \%$. SCoT1 exhibited the highest polymorphic percentage (80\%), followed by SCoT-2 and SCoT-3 with a percentage of polymorphism 76.9 and $77.77 \%$, respectively (Table 4); while SCoT- 28 recorded the lowest polymorphism percentage (35.71\%). SCoT-1 and SCoT-3 created two common bands with Mwt1200; 920 and 300; 200 respectively; whereas SCoT13 and SCoT-28 generated nine common bands. The results indicated that SCoT primers can differentiate between the Dictyota dichotoma genomes collected from the two studied localities and the primers with higher

Table (4): SCoT analyses of Dictyota dichotoma collected from Abu-Qir Bay and Hurghada shore. $\mathbf{M b}=$ monomorphic bands, $\mathbf{P b}=$ polymorphic bands, $\mathbf{P}=$ Polymorphism, $\mathrm{BSI}=\mathbf{b a n d}$ sharing index.

\begin{tabular}{lcccccc}
\hline $\begin{array}{l}\text { Primer } \\
\text { Code }\end{array}$ & bp Range & $\begin{array}{c}\text { Total No. } \\
\text { of bands }\end{array}$ & $\begin{array}{c}\text { No. of } \\
\text { Mb }\end{array}$ & $\begin{array}{c}\text { No. of } \\
\text { Pb }\end{array}$ & $\begin{array}{c}\text { \% of } \\
\text { P }\end{array}$ & $\begin{array}{c}\text { \% } \\
\text { BSI }\end{array}$ \\
\hline SCoT-1 & $270-2000$ & 10 & 2 & 8 & 80 & 0.4 \\
\hline SCoT-2 & $150-960$ & 13 & 3 & 10 & 76.92 & 0.46 \\
\hline SCoT-3 & $150-1000$ & 9 & 2 & 7 & 77.77 & 0.44 \\
\hline SCoT-4 & $190-1350$ & 13 & 8 & 5 & 38.46 & 1.23 \\
\hline SCoT-5 & $300-1900$ & 13 & 5 & 8 & 61.53 & 0.77 \\
\hline SCoT-11 & $350-1850$ & 20 & 11 & 9 & 45.00 & 1.10 \\
\hline SCoT-12 & $300-2000$ & 16 & 5 & 11 & 56.25 & 0.63 \\
\hline SCoT-13 & $220-2000$ & 15 & 9 & 6 & 40.00 & 1.20 \\
\hline SCoT-14 & $180-2000$ & 16 & 5 & 11 & 68.75 & 0.63 \\
\hline SCoT-20 & $270-1800$ & 16 & 8 & 8 & 50.00 & 1.00 \\
\hline SCoT-22 & $200-1350$ & 12 & 5 & 7 & 58.33 & 0.63 \\
\hline SCoT-28 & $290-1400$ & 14 & 9 & 5 & 35.71 & 1.29 \\
\hline SCoT-33 & $310-1900$ & 20 & 7 & 13 & 65.00 & 0.7 \\
\hline Total & & 187 & 81 & 106 & 56.68 & 0.87 \\
\hline
\end{tabular}


polymorphic bands are more effective in studying genetic variation.

\section{Genetic variation in Sargassum dentifolium}

The SCoT fingerprinting pattern of Sargassum dentifolium detected by thirteen primers is shown in Fig. (1) and Table (5). SCoT primers amplified a total number of 172 bands, of which 106 were polymorphic fragments and 66 monomorphic markers. The mean number of polymorphic bands per primer was 3.2 and the total average of polymorphism is $61.63 \%$. SCoT-3 exhibited higher polymorphism (90\%) compared to SCoT-13 exhibited the lowest polymorphism $(0.09 \%)$. SCoT-3 created one unique band with Mwt. 380, while SCoT-13 generated ten common monomorphic bands. The results also showed that SCoT primers can differentiate among the Sargassum dentifolium genotypes collected from the two studied sites.

In this study, variability in band profiles were observed in which some new bands were appeared and others were disappeared. Savva et al. (1994) showed that DNA fingerprints will be altered by factors such as exposure of an organism to a genotoxic chemical which may result in the formation of covalently bound adduct between the chemical and the DNA. Faulty repair of these adducts may prevent the primer from binding to those sites command to mutations and, sometimes to cytogenetic changes. Atienzar and Jha (2004 and 2006) used RAPD technique and confirmed that when the Taq DNA polymerase encounters a DNA adduct, there are several possible results including blockage, by-pass and the possible dissociation of the enzyme/adduct complex which will cause changes in RAPD profiles. Breakages which take place in the DNA template between two opposite primers may result in a loss of an amplicon whereas genetic rearrangements and point mutations may be accountable for either a loss or induction of new annealing sites which could result in the disappearance or appearance of new amplicons, respectively. The appearance of bands could be referring to the presence of new sites which become accessible to primers after structural modulation in DNA sequence that occurred due to mutations (resulting in new annealing events) or large deletions (bringing two preexisting annealing sites closer) or recombination; while the disappearance of bands may be attributed to the presence of DNA adducts, which can act to block or reduce the polymerization of DNA in the PCRreaction (Jones \& Parry, 1992).

Biotechnological methods and molecular markers are great promising tools for improvement and enhancement of biomass production in algae (Boegle et al., 2007 and

Table (5). SCoT analyses of Sargassum dentifolium collected from Abu-Qir Bay and Hurghada shore. $\mathbf{M b}=$ monomorphic bands, $\mathbf{P b}=$ polymorphic bands, $\mathbf{P}=$ Polymorphism, BSI $=$ band sharing index.

\begin{tabular}{lcccccc}
\hline $\begin{array}{l}\text { Primer } \\
\text { Code }\end{array}$ & $\begin{array}{c}\text { bp } \\
\text { Range }\end{array}$ & $\begin{array}{c}\text { Total No. } \\
\text { of bands }\end{array}$ & $\begin{array}{c}\text { No. of } \\
\text { Mb }\end{array}$ & $\begin{array}{c}\text { No. of } \\
\text { Pb }\end{array}$ & $\begin{array}{c}\text { \% of } \\
\text { P }\end{array}$ & $\begin{array}{c}\text { \% } \\
\text { BSI }\end{array}$ \\
\hline SCoT-1 & $200-3000$ & 15 & 4 & 11 & 73.33 & 0.53 \\
\hline SCoT-2 & $150-1300$ & 9 & 4 & 5 & 55.55 & 0.89 \\
\hline SCoT-3 & $370-1550$ & 10 & 1 & 9 & 90.00 & 0.20 \\
\hline SCoT-4 & $150-2000$ & 14 & 6 & 8 & 57.14 & 0.86 \\
\hline SCoT-5 & $280-2000$ & 11 & 4 & 7 & 63.63 & 0.73 \\
\hline SCoT-11 & $280-1500$ & 14 & 4 & 10 & 71.43 & 0.57 \\
\hline SCoT-12 & $230-2000$ & 12 & 9 & 3 & 11.11 & 1.50 \\
\hline SCoT-13 & $290-1700$ & 11 & 10 & 1 & 0.09 & 1.82 \\
\hline SCoT-14 & $200-1500$ & 19 & 5 & 14 & 73.68 & 0.53 \\
\hline SCoT-20 & $270-2000$ & 12 & 7 & 5 & 41.67 & 1.17 \\
\hline SCoT-22 & $240-1500$ & 15 & 3 & 12 & 80.00 & 0.40 \\
\hline SCoT-28 & $250-1400$ & 14 & 4 & 10 & 71.43 & 0.57 \\
\hline SCoT-33 & $260-2100$ & 16 & 5 & 11 & 68.75 & 0.63 \\
\hline Total & & 172 & 66 & 106 & 61.63 & 0.77 \\
\hline
\end{tabular}




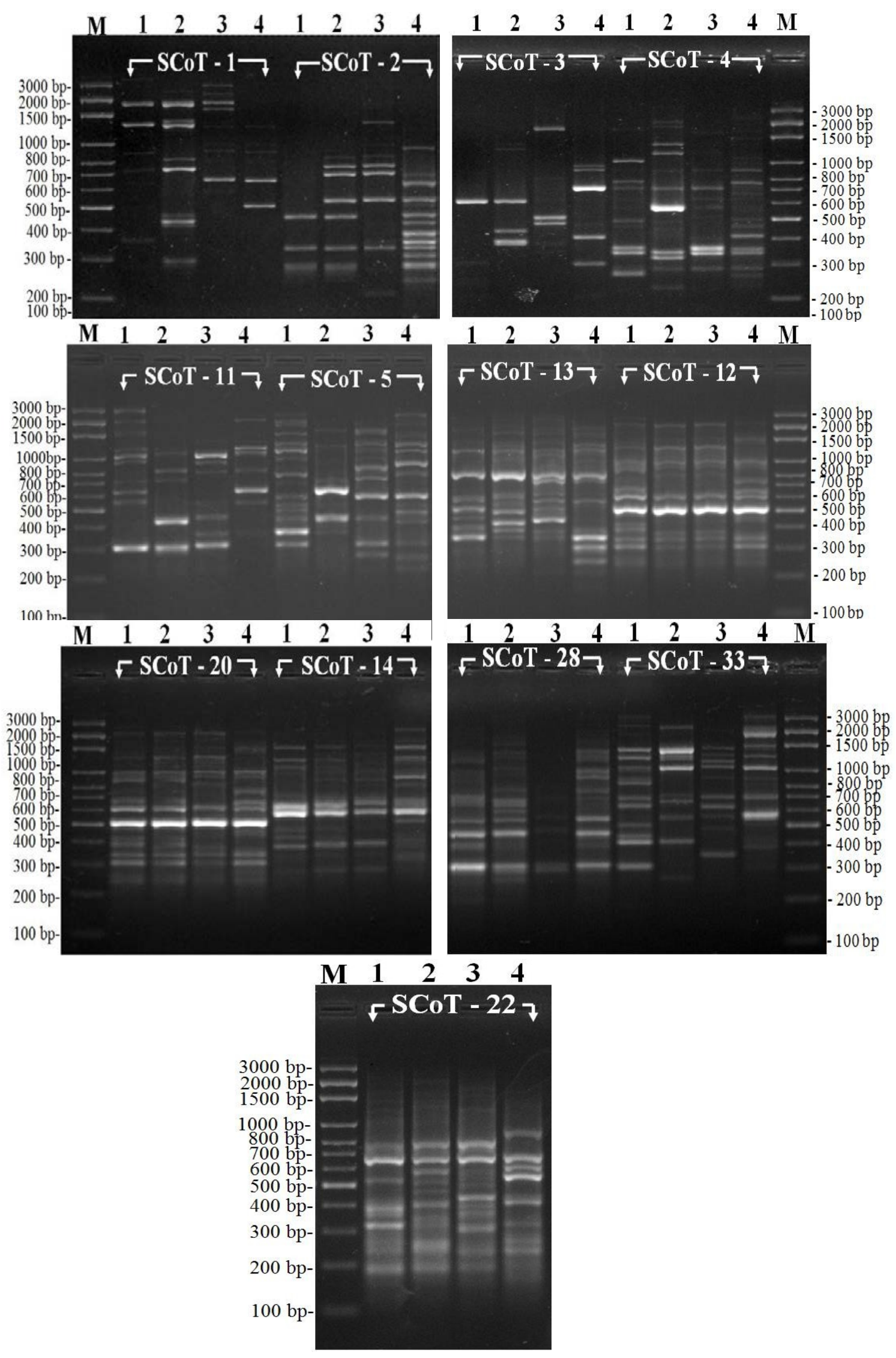

Figure 1: Thirteen SCoT finger printings of (1) Dictyota dichotoma collected from Alexandria, (2) Sargassum dentifolium collected from Alexandria, (3) $S$. dentifolium collected from Hurghada, (4) D. dichotoma collected from Hurghada. M: DNA marker. 
Abd El Fatah et al., 2015). There have been some studies on algae using Inter Simple Sequence Repeat (ISSR) and Random Amplified Polymorphic DNA (RAPD) molecular markers (Barakat et al., 1999 and 2002 and Hall and Vis, 2002); however, there have been none thus far on Dictyota dichotoma and Sargassum dentifolium. Hanyuda et al. (2018) investigated genetic identification of macroalgal species on Japanese tsunami marine debris and genetic comparisons with their wild populations by using molecular marker. Also, SCoT-PCR technique was applied to numerous plant genetic studies as it overcomes most limitations of other markers. Molecular markers are predictable to create new awareness and improve our understanding of the genetics of complex traits (Ren et al., 2015).

A dendrogram obtained from UPGMA cluster based on SCoT analysis can separate the two algal species (Dictyota dichotoma and Sargassum dentifolium) into two groups, the first group includes samples 1 \& 4 (Dictyota dichotoma collected from Abu-Qir Bay and Hurghada shore), while the second group includes samples 2 \& 3 (Sargassum dentifolium collected from Abu-Qir Bay and Hurghada shore) (Fig.2). The cluster results of this study showed a closed genetic distance between genotypes $1 \& 4$ and between genotypes $2 \& 3$.

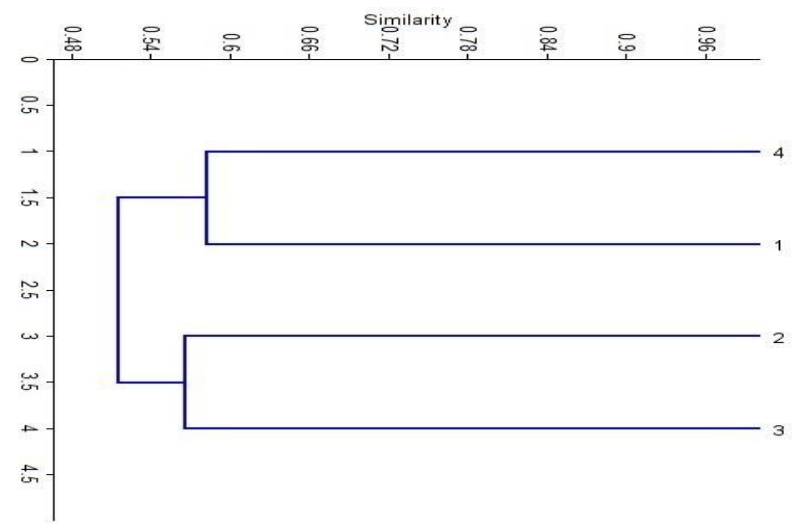

Figure 2. Dendogram for (1) Dictyota dichotoma collected from Alexandria, (2) Sargassum dentifolium collected from Alexandria, (3) S. dentifolium collected from Hurghada, (4) D. dichotoma collected from Hurghada, constructed from SCoTs data using UPGMA.
The value of Band Sharing Index (BSI) for each species collected from Abu-Qir Bay and Hurghada shore based on SCoT analysis was calculated and the results showed that $D$. dichotoma BSI has higher percentage $(0.87 \%)$ as compared with $0.77 \%$ that was recorded in S. dentifolium.; indicating more DNA variation in S. dentifolium genotype (Tables 4 \& 5). The higher the similarity coefficient between two genotypes, the more the similarity between them (Aghili et al., 2012 and Sarkar et al., 2015). These results indicated that Sargassum dentifolium is more genetically affected by stress condition than $D$. dichotoma and can be used as a bioindicator. Changes in bands may be the consequences of genomic template instability (GTS) related to the level of DNA damage, the efficiency of DNA repair and replication (Atienzar et al., 2002; Atienzar and Jha, 2004 and Ciğerci et al., 2016). Yu et al. (2013) reported that high genetic variability and differentiation existed among Sargassum horneri populations using ISSR and RAPD. They also reported that the genetic differentiation of $S$. horneri populations along China's coast agreed with the geographic isolation, but some populations are genetically closer than others, even when these populations are widely separated geographically. Natural selection factors, geographical distance and ecological factors, such as temperature and salinity, in specific geographical location influence the genetic variation of living organisms (Sun and Lin, 2003).

\section{Conclusion}

In conclusion, the present study confirms that changing geographical localities affects both the genetic variation and chemical constituents of Sargassum dentifolium and Dictyota dichotoma. However, S. dentifolium thought to be more tolerant to stress than $D$. dichotoma. But further work is needed to pinpoint the exact factors that cause the difference and the mechanism by which these algae respond to different environmental conditions. Additionally, results of the present study verify the efficiency of SCoT markers to discriminate between algal species collected from different localities. 


\section{Acknowledgment}

Thanks are due to Mr. Ahmed Yusuf Mohamed, an assistant lecturer at Botany Department, Faculty of Science, Ain Shams University, Egypt for collecting macroalgal samples used in the present study.

\section{References}

Abd El Fatah, H. M., Ibrahim, M. and Ibrahim, S. D. (2015) Morphological and molecular diversity among selected Chara L. species (Characeae) from different habitats in Egypt. Egypt. J. Exp. Biol. (Bot.), 11(2): 129 139.

Abdel Ghani, S., El Zokm, G., Shobier, A., Othman, T. and Shreadah, M. (2013) Metal pollution in surface sediments of Abu-Qir Bay and Eastern Harbour of Alexandria, Egypt. Egypt. J. Aquat. Res., 39: 1-12.

Agarwal, A., Gupta, V., Haq, S. UI., Jatav, P. K., Kothari, S. L. and Kachhwaha, S. (2019) Assessment of genetic diversity in 29 rose germplasms using SCoT marker. J. King Saud Univ. Sci., 31:780-788.

Aghili, P., Imani, A. A. and Alaei, Y. (2012) A study on genetic diversity in lentil genotypes using seeds morphologic and protein traits. Life Sci. J., 9(4): 4099- 4106.

Aleem, A.A. (1993) The marine algae of Alexandria, Egypt. 138 pp. Egyptian Books House.

Ali, I., Manzoor, Z, Koo, JE., Kim, JE., Byeon, SH., Yoo, ES., Kang, HK., Hyun, JW., Lee, NH. and Koh, YS. (2017) 3Hydroxy-4,7-megastigmadien-9- one, isolated from Ulva pertusa, attenuates TLR9-mediated inflammatory response by down-regulating mitogen-activated protein kinase and NFkappa B pathways. Pharm. Biol.: 55: 435-40.

APHA (2005) Standard Methods for Examination of Water and Wastewater. $20^{\text {th }}$ ed. Washington: American Public Health Association, $1360 \mathrm{pp}$.

Atienzar, F.A. and Jha, A.N. (2004) The random amplified polymorphic DNA (RAPD) assay to determine DNa alterations, repair and transgenerational effects in $\mathrm{B}(\mathrm{a}) \mathrm{P}$ exposed Daphnia magna. Mutat. Res., 552: 125-140.

Atienzar, F.A. and Jha, A.N. (2006) The random amplified polymorphic DNA (RAPD) assay and related techniques applied to genotoxicity and carcinogenesis studies: a critical review. Mutat. Res., 613: 76-102.

Atienzar, F.A., Venier, P., Jha, A.N. and Depledge, M.H. (2002) Evaluation of the random amplified polymorphic DNA (RAPD) assay for the detection of DNA damage and mutations. Mutat. Res., 521(1-2):151-163.

Baleta, FN., Bolaños, JM., Ruma, OC., Baleta, AN. and Cairel, JD. (2017) Phytochemicals screening and antimicrobial properties of Sargassum oligocystum and Sargassum crassifolium extracts. J. Med. Plants Stud., 5(1): 382-387.

Barakat, H.M., Shehata, M.M., El-Atroush, H., El-Kodary, S. and Salama, M.S. (1999) Genetic variability among two Medicago species, analyzed using random amplified polymorphic DNA and protein electrophoresis techniques. $6^{\text {th }}$ Inter. Confer. J. Union Arab Biol., Cairo 9(B) 8-10 Nov.:1-13.

Barakat, H.M., Shehata, M.M., El-Atroush, H., El-Kodary, S. and Salama, M.S. (2002) DNA Fingerprinting markers for Medicago sativa L. and Medicago polymorpha L. using RAPD-PCR. Egypt. J. Bot., 42(1-2): 21-31.

Blakeney, A.B. and Mutton, L.L. (1980) A simple colorimetric method for the determination of sugars in fruits and vegetables. J. Sci. Food Agri.: 31, 889-897.

Boegle, M.G., Schneider, S., Mannschreck. B. and Melzer A. (2007). Differentiation of Chara intermedia and C. baltica compared to C. hispida based on morphology and amplified fragment length polymorphism. Hydrobiol., 586: 155-166.

Bruton, T., Lyons, H., Lerat, Y., Stanley, M. and Rasmussen, M. B. (2009) A review of the potential of marine algae as a source of biofuel in Ireland; Sustainable Energy Ireland: Dublin, Ireland.

Chai, T.T., Kwek, M.T., Ismail, N.I.M., Ooi, J.L.S., Amri, A.Y., Manan, F.A., Law, Y.C. and Wong, F.C. (2015) Antioxidant activities of methanol extract and solvent fractions of marine macroalga, Avrainvillea erecta (Berkeley) A.Gepp and E.S. Gepp (Dichotomosiphonaceae). Trop. J. Pharm. Res., 14: 503-509.

Chen, H., He, X.H., Luo, C., Zhu, J.H. and Li., F. (2010) Analysis on the genetic diversity of 24 longan (Dimocarpus longan) accessions by SCoT markers," Acta Bot. Sin., 37(10): 1651-1654. 
Chikkaswamy, B.K. and Paramanik, R.C. (2016). Molecular Distinction of algae using Molecular Marker. Int. J. Curr. Microbiol. App. Sci., 5(9): 489-495.

Cho, M., Lee, H.S., Kang, I.J., Won, M.H. and You, S. (2011) Antioxidant properties of extract and fractions from Enteromorpha prolifera, a type of green seaweed. Food Chem., 127, 999-1006.

Ciğerci, I.H., Cenkci, S., Kargioglu, M. and Konuk, M. (2016) Genotoxicity of Thermopsis turcica on Allium cepa roots by alkaline comet and random amplified polymorphic DNA assays. Cytotechnol., 68: 829-838.

Collard, B.C.Y. and Mackill, D.J. (2009) Start codon targeted (SCoT) polymorphism: a simple, novel DNA marker technique for generating gene-targeted markers in plants. Plant Mol. Biol. Report., 27: 86-93.

Connan, S. and Stengel, D. B. (2011) Impacts of ambient salinity and copper on brown algae: 2. Interactive effects on phenolic pool and assessment of metal binding capacity of phlorotannin. Aquat. Toxicol.,14: 1-13.

Dawes C. J., and Mathieson, A. C. (2008) The Seaweeds of Florida. University Press of Florida, Gainesville.

de la Coba, F. Aguilera, J. Figueroa, F. L., de Galvez, M. V. and Herrera, E. (2009) Antioxidant activity of mycosporine-like amino acids isolated from three red macroalgae and one marine lichen. J. Appl. Phycol., 21: 161-169.

Demirel, Z., Yilmaz-Koz., F.F., KarabayYavasoglu, U. N., Ozdemir, G. and Sukatar, A. (2009) Antimicrobial and antioxidant activity of brown algae from the Aegean Sea., J. Serb. Chem. Soc., 74(6): 619-628.

Deyab, A., Elkatony, T. and Ward, F. (2016) Qualitative and quantitative analysis of phytochemical studies on brown seaweed, Dictyota dichotoma. Int. J. Eng. Dev. Res., 4(2): 2321-9939.

Deyab, A., Elkatony, T., El-Adl, M. F. and Ward, F. (2017) Temporal variation in chemical composition of Dictyota dichotoma (Hudson) J.V. Lamouroux (Dictyotales, Phaeophyceae) from Red Sea Coast, Egypt. $J$. Coast. Life Med., 5(4): 149-155.

El- Gohary, S.E., El-Naggar, M.F. and Zaki, H. R. (2011) Study on water quality along the coastal zone of Abu- Qir Bay, Mediterranean Sea, Alexandria, Egypt. Egypt. J. Aquat. Res., 37(3): 209-219.

Elsaied, H. E., Hassaan, M. and Abu Taleb, H. T. (2015) Genetic and nutritional characterization of some macrophytes, inhabiting the Bardawil Lagoon, Sinai, Egypt. Egypt. J. Aquat. Res., 41: 315- 322.

Emam, W.M., Saad, A.A., El-Moselhy, K.M. and Owen, N.A. (2013) Evaluation of water quality of Abu-Qir Bay, Mediterranean coast, Egypt. Int. J. Environ. Sci. Eng., 4: 4754.

Fathy, A. A. (2007) Evaluation of nutritional composition of some attached and drifted marine algae from Alexandria, Egypt. Egypt. J. Phycol. 8: 131-141.

Farghl, A. A. M., Shaddad, M. A. K., Galal, H. R. and Hassan, E. A. (2015) Effect of salt stress on growth, antioxidant enzymes, lipid peroxidation and some metabolic activities in some fresh water and marine algae. Egypt. $J$. Bot., 55(1): 1-15.

Freile-Pelegrin, Y. and Robledo, D. (2014) Bioactive Phenolic Compounds from Algae. In: B. Hernandez-Ledesma and M. Herrero (eds.). Bioactive Compounds from Marine Foods: Plant and Animal Sources. John Wiley \& Sons, Ltd., pp.113-129.

Gamal-Eldeen, A.M., Abo-Zeid, M.A.M. and Ahmed, E.F. (2013) Anti-genotoxic effect of the Sargassum dentifolium extracts: Prevention of chromosomal aberrations, micronuclei, and DNA fragmentation. Exp. Toxicol. Pathol., 65: 27-34.

Geelani, S., Bhat, S. J. A., Hanifa, G. S. and Haq, S. (2012) Pollution indicators and their detection. J.Pl. Sci. Res., 28 (2): 55-59.

Ghasemzadeh, A. and Ghasemzadeh, N. (2011) Flavonoids and phenolic acids: Role and biochemical activity in plants and human. J. Med. Plants Res., 5(31): 6697-6703.

Gill, P.K., Sharma, A.D., Singh, P. and Bhullar, S.S. (2002) Osmotic stress induced changes in germination, growth and soluble sugar contents of Sorghum bicolor (L.) Moench seeds under various abiotic stresses. Plant Physiol., 128: 12-25.

Gorji, A.M., Poczai, P., Polgar, Z. and Taller, J. (2011) Efficiency of arbitrarily amplified dominant markers (SCoT, ISSR and RAPD) for diagnostic fingerprinting in 
tetraploid potato. Am. J. Potato Res., 88(3): 226-237.

Gosch, B. J., Magnusson, M., Paul, N. A. and Nys, R. (2012) Total lipid and fatty acid composition of seaweeds for the selection of species for oil-based biofuel and bioproducts. Glob. Chang. Biol. Bioenergy, 4(6): 919-930.

Hall, M. M. and Vis, M. L. (2002) Genetic variation in Batrachospermum helminthosum (Batrachospermales, Rhodophyta) among and within stream reaches using intersimple sequence repeat molecular markers. Phycol. Res., 50: 155-162.

Hanyuda, T., Hansen, G. I. and Kawai, $H$. (2018) Genetic identification of macroalgal species on Japanese tsunami marine debris and genetic comparisons with their wild populations. Mar. Pollut. Bull., 132: 74-81.

Hashem, H.A., Mansour, H.A., El-Khawas, S.A. and Hassanein, R.A. (2019) The potentiality of marine macro-algae as biofertilizers to improve the productivity and salt stress tolerance of Canola (Brassica napus L.) plants. Agronomy, 9(3): 146.

Hemaida, H. A. E. (2007) Impact of drainage effluents on the water quality of Abu-Qir Bay, Alexandria, Egypt. Bull. High Inst. Public Health, 37(1): 155-168.

Hiremath, S. and Mathad, P. (2010) Impact of salinity on the physiological and biochemical traits of Chlorella vulgaris Beijerinck. J. Algal Biomass Utln, 1: 51-59.

Homme, P. M., Gonalez, B. and Billard, J. (1992) Carbohydrate content, fructane and sucrose enzyme activities in roots, stubble and leaves of rye grass (Loliumperenne L.) as affected by source/sink modification after cutting. J. Plant Physiol., 140: 282-291.

Hwang, E S. and Do Thi, N. (2014) Effects of extraction and processing methods on antioxidant compound contents and radical scavenging activities of Laver (Porphyra tenera). Prev. Nutr. Food Sci., 19: 40-48.

Ibrahim, S.D., Adawy, S.S., Atia, M.A.M., Alsamman, A.M. and Mokhtar, M.M. (2016) Genetic diversity, variety identification and gene detection in some Egyptian grape varieties by SSR and SCoT markers. POJ, 9 (5): 311-318.

Ismail, M.M. and Mohamed, S.E. (2017). Differentiation between some Ulva spp. by morphological, genetic and biochemical analyses. Journal of Genetics and Breeding, 21(3):360-367.

Jones, N.J. and Parry, J.M. (1992) The detection of DNA adducts, DNA base changes and chromosome damage for the assessment of exposure to genotoxic pollutants. Aquat. Toxicol., 22: 323-344.

Jormalainen, V. and Honkanen, T. (2008) Macroalgal chemical defenses and their roles in structuring temperate marine communities. In: Amsler, C. D. (ed.). Algal Chemical Ecology, Springer- Verlag: Berlin, Heidelberg, Germany, pp. 57-89.

Karsten, U. and Kirst, G. O. (1989) The effect of salinity on growth, photosynthesis and respiration in the estuarine red alga Bostrychia radicans Mont. Helgoländer Meeresuntersu-chungen, 43: 61 - 66.

Khallil, A.M., Daghman, I.M. and Fady, A.A. (2015) Antifungal potential in crude extracts of five selected brown seaweeds collected from the Western Libya Coast. $J$. Microbial. Modern Tech., 1(1): 103-110.

Kim, S.K. (2012). Handbook of Marine Macroalgae: Biotechnology and Applied Phycology, John Wiley \& Sons.

Kirrolia, A., Bishnoia, R.N. and Singh, N. (2011) Salinity as a factor affecting the physiological and biochemical traits of Scenedesmus quadricauda. J. Algal Biomass Utilization, 2(4): 28-34.

Luo, C., He, X.H., Hu, Y., Yu, H.X., Ou, S.J. and Fang, Z.B. (2014) Oligo-dT anchored cDNA-SCoT: a novel differential display method for analyzing differential gene expression in response to several stress treatments in mango (Mangifera indica L.). Gene, 548: 182-189.

Maddah, M., Huwait, E.A., Al-balawi, A., Moselhy, S., ALghamdi, M. A., Zeyadi, M., Al-Malki, A. L., and Kumosani, T. A. (2019) In vitro study anti-proliferative potential of algae extract against cancer cell line. J. Pharm. Res. Int., 26(1): 1-10.

Madkour, F.F.; El-Shoubaky, G.A. and Ebada, M.A. (2019) Antibacterial activity of some seaweeds from the Red Sea coast of Egypt. Egypt. J. Aquat. Biol. Fish., 23(2): 265 $-274$.

Madkour, F. F., Khalil, W. F. and Dessouki, A. A. (2012) Protective effect of ethanol extract of Sargassum dentifolium 
(Phaeophyceae) in carbon tetrachloride induced hepatitis in rats. Int. J. Pharm. Sci., 4(3): 637-641.

Mamelona, J., Pelletier, É., GirardLalancette, K., Legault, J., Karboune, S.and Kermasha, S. (2007) Quantification of phenolic contents and antioxidant capacity of Atlantic sea cucumber, Cucumaria frondosa. Food Chem., 104: 1040-1047.

Mannschreck, B., Fink, T. and Melzer, A. (2002) Biosystematics of selected Chara species (Charophyta) using amplified fragment lengths polymorphism (AFLP). Phycologia, 41, 657-66.

Mansour, H. A., Emam, M. M. and Mostafa, N. H. (2018) Influence of different habitats on the chemical constituents of Codium tomentosum. Egypt. J. Bot., 58(2): 275 - 285. Mathieson, A.C.; Norton, A.T. and Neushul, M. (1981). The taxonomic implications of genetic and environmentally induced variations in seaweed morphology. Bot. Rev., 47(3): 313-347.

Matloub, A. A., Awad, N. E. and Khamiss, O. A. (2012) Chemical composition of some Sargassum spp. and their insecticidal evaluation on nucleopolyhedrovirus replication in vitro and in vivo. Egypt. Pharm. J., 11: 53-8.

Metzner, H., Rau, H. and Senger, H. (1965) Untersuchungen zur Synchronisierbark eiteinzelner Pigmentmangel Mutanten von Chlorella. Plant, 65: 186.

Mohamed, S.S. and Saber, A.A. (2019) Antifungal potential of the bioactive constituents in extracts of the mostly untapped brown seaweed from the Egyptian coastal waters. Egypt. J. Bot., 59(3): 1- 14.

Munir, N., Sharif, N., Naz, S. and Manzoor, F. (2013) Algae: A potent antioxidant source. Sky J. Microbiol. Res., 1(3): 22 - 31.

Naguib, M.I. (1963) Colourimetric estimation of plant polysaccharides. Zucher, 16: 15-18.

Pinteus, S., Silva, J., Alves, C., Horta, A., Fino, N., Rodrigues, A.I., Mendes, S. and Pedrosa, R. (2017) Cytoprotective effect of seaweeds with high antioxidant activity from the Peniche coast (Portugal). Food Chem., 218:591-599.

Que, Y., Pan, Y., Lu, Y., Yang, C., Yang, Y., Huang, N. and Xu., L. (2014) Genetic analysis of diversity within a Chinese local sugarcane germplasm based on start codon targeted polymorphism. Bio. Med. Res. Int., pp. 10.

Rabanala, M., Poncea, N. M. A., Navarro, D. A., Gómez, R. M. and Stortza, C. A. (2014) The system of fucoidans from the brown seaweed Dictyota dichotoma: chemical analysis and antiviral activity. Carbohydrate Polymers, 101: 804-811.

Rajkumar, G., Bhavan, P. S., Suganya, M., Srinivasan, V., Karthik, M. and Udayasuriyan, R. (2018) Phytochemical characterization of marine macroalga Sargassum polycystem, molecular docking, and in vitro anti-bacterial activity against Psuedomonas aeruginosa. IBB J., 4(1): 35 47.

Rao, A.R., Dayananda, C., Sarada, R., Shamala, T.R. and Ravishankar, G.A. (2007) Effect of salinity on growth of green alga Botryococcus braunii and its constituents. Bioresour. Technol., 98: 560- 564.

Ren, J.R., Yang, R., He, Y.Y. and Sun, Q.H. (2015) Genetic variation of Sargassum horneri populations detected by inter-simple sequence repeats. Genet. Mol. Res., 14(1): 619-625.

Salem, W. M., Galal, H. and Nasr El-deen, F. (2011) Screening for antibacterial activities in some marine algae from the red sea (Hurghada, Egypt). Afr. J. Microbiol. Res., 5(15): 2160-2167.

Sarkar, S.D., Chaudhari, A., Deshmukhe, G. and Babu, P.G. (2015) Note Assessment of genetic diversity among Sargassum species from selected locations along the north-west coast of India. Indian J. Fish., 62(3): 161-165. Savva D. (2000) The use of arbitrarily primed PCR (AP-PCR) fingerprinting detects exposure to genotoxic chemicals. Ecotoxicol., 9: $341-353$.

Savva, D., Castellani, S., Mattei, N., Renzoni, A. and Walker, C.H. (1994) The use of PCR and DNA fingerprints to detect the genotoxic effects of environmental chemicals. In: S.P. Varnavas (ed.), Environmental Contamination, (CEP Consultants, Edinburgh), pp 105-110.

Sawant, S.V., Singh, P.K., Gupta, S. K., Madnala, R. and Tuli, R. (1999) Conserved nucleotide sequences in highly expressed genes in plants. J. Genet., 78: 123-131.

Sigaud, T.C.S. and Aidar, E. (1993) Salinity 
and temperature effects on the growth and chlorophyll-a content of some planktonic algae. Bolm. Inst. Oceanogr., S. Paulo., 41(1/2): 95-103.

Sjøtun, K., Husa1, V., Asplin, L. and Sandvik, A. D. (2015) Climatic and environmental factors influencing occurrence and distribution of macroalgae - a fjord gradient revisited. Mar. Ecol. Prog. Ser., 532: 73-88.

Sneath, P. and Sokal, R. (1973) Numerical taxonomy. San Francisco, California.

Sokal, R. and Michener, C. (1958) A statistical method for evaluating systematic relationships. Univ. Kansas Sci. Bull., 38: 1409-1438.

Sujatha, R., Siva, D. and Nawas, P.M.A. (2019) Screening of phytochemical profile and antibacterial activity of various solvent extracts of marine algae Sargassum swartzii. World Scientific News, 115: 27-40.

Sun, Y. and Lin, FC. (2003) Analysis of genetic diversity in natural germplasm of Lentinula edodes in China using RAPD technique. Mycosystema, 22: 387-393.

Ward, F., Deyab, A. and El-katony, T. (2017) Biochemical composition and bioactivity of Dictyota from Egypt. Lap Lambert Academic Publishing.

Wolf, M.A., Sciuto, K., Andreoli, C. and
Moro, I. (2012). Ulva (Chlorophyta, Ulvales) biodiversity in the North Adriatic Sea (Mediterranean Italy): Cryptic species and new introductions. J. Phycol., 48:1510- 1521.

Yende, S.R., Harle, U.N.., Arora, S.K. and Pande, V.B. (2018) Phytochemical screening and anticonvulsant activity of Sargassum ilicifolium (brown algae) in mice. $J$. Phytopharmacol., 7(1): 25-28.

Yu, SH, Chong, Z., Zhao, FJ. and Yao, JT. (2013) Population genetics of Sargassum horneri (Fucales, Phaeophyta) in China revealed by ISSR and SRAP markers. Chin. J. Oceanol. Limnol., 31: 609-616.

Yuan, Y.V., Bone, D.E. and Carrington, M.F. (2005) Antioxidant activity of dulse (Palmaria palmata) extract evaluated in vitro. Food Chem., 91: 485-494.

Žilić, S., Serpen, A., Akillioğlu, G., Janković, M. and Gökmen, V. (2012) Distributions of phenolic compounds, yellow pigments and oxidative enzymes in wheat grains and their relation to antioxidant capacity of bran and debranned flour. J. Cereal Sci., 56: 652-658.

Zubia, M., Robledo, D. and Freile-Pelegrin, Y. (2007) Antioxidant activities in tropical marine macroalgae from the Yucatan Peninsula, Mexico. J. Appl. Phycol., 19: 449458. 